\title{
Eye Colour as a Genetic Marker for Fertility and Fecundity of Triatoma infestans (Klug, 1834) Hemiptera, Reduviidae, Triatominae
}

\author{
Herton Helder Rocha Pires/ ${ }^{+}$, Daniele Oliveira Abrão, Evandro Marques de Menezes \\ Machado, Christopher John Schofield*, Liléia Diotaiuti
}

\begin{abstract}
Laboratório de Triatomíneos e Epidemiologia da Doença de Chagas, Centro de Pesquisas René Rachou-Fiocruz, Av. Augusto de Lima 1715, 30190-002 Belo Horizonte, MG, Brasil *Department of Infectious and Tropical Diseases, London School of Hygiene and Tropical Medicine, London, UK

Eye colour of Triatoma infestans is controlled at a single autosomal locus, with black-eye as the dominant gene and red-eye as the recessive. Inheritance of these characters follows a classical Mendelian system, enabling eye colour to be used as a marker for studies of mating frequency. We found no significant differences in oviposition rates and egg hatching rates irrespective of parental phenotypes. Different mating schedules between red-eye and blackeye parents showed that eye colour did not affect mating competence. Females mated with a single male or with different males together or in succession produced similar numbers of fertile eggs, with the eye colour of the offspring reflecting exposure to the different males. We conclude that although a single mating can provide sufficient sperm for the whole reproductive life of the female, multiple matings can result in balanced assortative sperm usage from the spermatheca.
\end{abstract}

Key words: Triatominae - Triatoma infestans - eye colour - fertility - fecundity

Eye colour in Triatoma infestans (Klug, 1834) is a genetically controlled character involving a single locus. Wild forms normally have black coloured eyes, although these often fade to grey after death. Red eyed forms have also been reported, and shown to be associated with a single recessive autosomal mutation (Wygodzinsky \& Briones 1954, 1955, Dujardin \& Bermúdez 1986). We report here a series of experiments using the red-eye mutation as a marker to investigate fertility and fecundity of T. infestans, in particular to examine the role of multiple mating in fertility.

Once fertilized, the female Triatominae generally remain fertile for life, by storing spermatozoa in a pair of structures named seminal receptacles or spermatheca. Some authors have reported that a single mating may be enough for the females to become fertile (Neiva 1910, Perlowagora-Szumlewicz 1968, Pessoa \& Martins 1982) although multiple mating is known to occur (Borba 1972, Lima et al. 1987). Manrique and Lazzari (1994) suggest a polyandrous fecundation system in T. infestans, whereby the female mates successively with several males. This might contribute to higher genetic variability, partially compensating the trend of genetic simplification believed to be associated with domestication (Schofield 1994). Considering this, the aim of the current work was to analyse such proposition using eye colour as a genetic marker of parentage.

Financial support: Fiocruz

${ }^{+}$Corresponding author. Fax: +55-31-3295.3566. E-mail: tim@cpqrr.fiocruz.br

Received 25 September 2001

Accepted 12 December 2001

\section{MATERIALS AND METHODS}

The $T$. infestans came from two colonies maintained in the insectary of the Laboratório de Triatomíneos e Epidemiologia da Doença de Chagas of the Centro de Pesquisas René Rachou-Fiocruz, Belo Horizonte, MG, Brazil, fed weekly on albino mice anaesthetized with Thionembutal. The first colony originated from insects captured in Cruz Del Eje, Argentina, and were homozygous recessive for red-eye. The second colony originated from the State of Minas Gerais, Brazil, and were homozygous dominant for normal black-eye. The homozygous character of both populations was confirmed by previous crosses of adults of the two colonies. These crosses invariably gave $100 \%$ black-eye at the F1 which, when mated together, gave F2 generations with black or red-eyes in proportions not significantly different from 3:1. In all cases, the black or red-eye phenotype is apparent in all nymphal stages as well as the adults.

For the present study, insects were separated individually as fifth instar nymphs and sexed from morphology of the external genital plates, following Corrêa (1954). They were maintained individually until adult emergence, then mated according to the scheme described below.

The first experiments involved five different mating schedules, designed to verify female fertility and hatching rate of the eggs, as well as inheritance of eye colour (Groups 1-5). Two subsequent experiments involved changing the mates after 15 days (Groups 6-7) when only inheritance of eye colour was monitored (Table). To verify the phenotypes expressed by the descendents of each group, eggs were collected weekly and maintained in separate groups until hatching. 
TABLE

Experimental groups, mating schemes and number of couples involved in each group

\begin{tabular}{|c|c|c|}
\hline Group & Mating scheme & $\begin{array}{l}\text { No. of } \\
\text { couples }\end{array}$ \\
\hline 1 & $\begin{array}{l}\text { Red-eyed female X red-eyed male. After the } \\
\text { beginning of the oviposition, the males were } \\
\text { replaced with homozygous black-eyed males. }\end{array}$ & 3 \\
\hline 2 & $\begin{array}{l}\text { Red-eyed female X red-eyed male. After the } \\
\text { beginning of the oviposition the male was ex- } \\
\text { cluded and two months later, the females were } \\
\text { mated with homozygous black-eyed males. }\end{array}$ & 3 \\
\hline 3 & $\begin{array}{l}\text { Red-eyed female X red-eyed male. After the } \\
\text { beginning of the oviposition the male was } \\
\text { excluded, without replacement. }\end{array}$ & 3 \\
\hline 4 & $\begin{array}{l}\text { Red-eyed female X red-eyed male. There was } \\
\text { neither exclusion of the males nor substitutions. }\end{array}$ & 4 \\
\hline 5 & $\begin{array}{l}\text { Red-eyed female X red-eyed and black eyed } \\
\text { male, simultaneously. }\end{array}$ & 3 \\
\hline 6 & $\begin{array}{l}\text { Red-eyed female } X \text { red-eyed male. After } 15 \\
\text { days, the males were replaced with homozygous } \\
\text { black-eyed males for a further } 15 \text { days. }\end{array}$ & 3 \\
\hline 7 & $\begin{array}{l}\text { Red-eyed female X black-eyed male. After } 15 \\
\text { days, the males were replaced with homozygous } \\
\text { red-eyed males for a further } 15 \text { days. }\end{array}$ & us \\
\hline
\end{tabular}

\section{RESULTS}

After mating, $13.6 \%$ of females began oviposition in the second week, $27.3 \%$ began at the third week, $22.7 \%$ at the fourth, $13.6 \%$ at the fifth, $13.6 \%$ at the sixth, and $9 \%$ at the seventh week. Oviposition rates did not differ significantly between the different mating schedules (Fig. 1), and nor did the hatching rates of the eggs (Fig. 2).

In groups 1 and 2, where the red-eye females were firstly kept with red-eye males and then with black-eye males, a change in the phenotype of offspring began to be observed two weeks after the substitution (Figs 3, 4). In group 1, where the substitution was made just after the beginning of oviposition, the total of offspring was 41 red-eye $(12.2 \%)$ and 295 black-eye $(87.8 \%)$, whereas in group 2 where the substitution was made after two months, the total of offspring was 110 red-eye $(37.8 \%)$ and 181 black-eye $(62.2 \%)$. In group 5 , where the females were simultaneously kept with a red-eye male and a black-eye male, the descendents showed both patterns in similar proportions, 137 red-eye (56.8\%) and 104 black-eye (43.2\%) (Fig. 5). Both types of male were similarly accepted by the females, with no apparent phenotypic mating dominance or preference (group 5). The proportions of black-eye offspring broadly reflected the relative length of time that black-eye males were present with the females, indicating multiple mating and random assortment of sperm within the spermatheca.

In groups 3 and 4, where the females were mated only with red-eye males, the red-eye phenotype of the offspring was maintained (detailed results not shown), and there

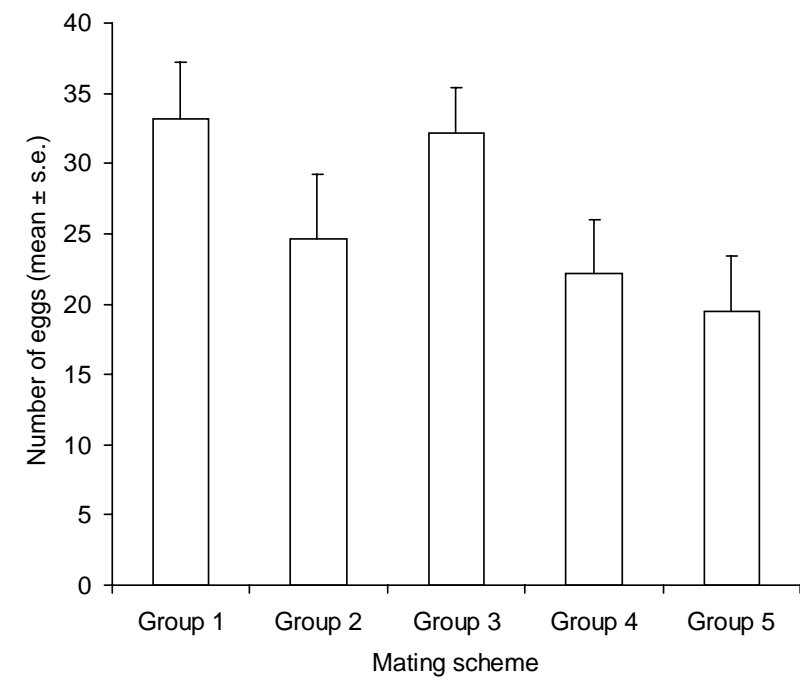

Fig. 1: mean number of eggs for the different mating schemes of Triatoma infestans, with recessive (red-eye) or dominant phenotype (black-eye).

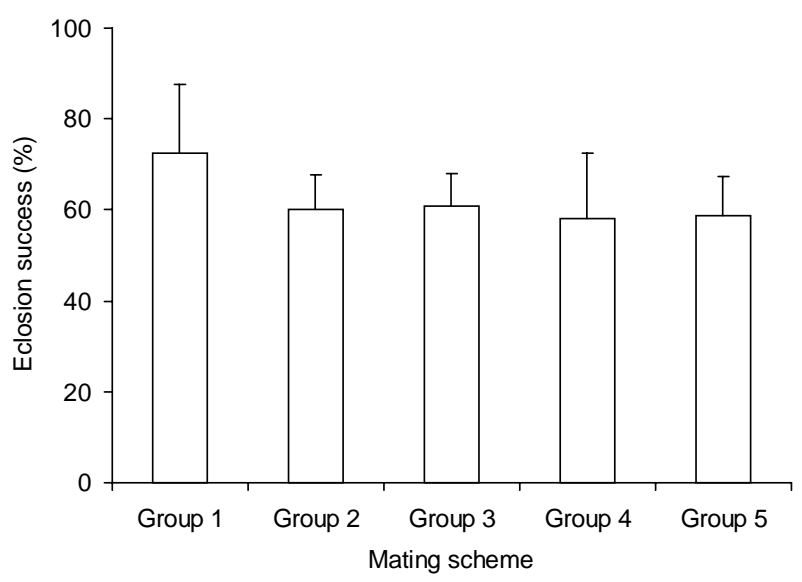

Fig. 2: hatching of the Triatoma infestans eggs from five different forms of mate.

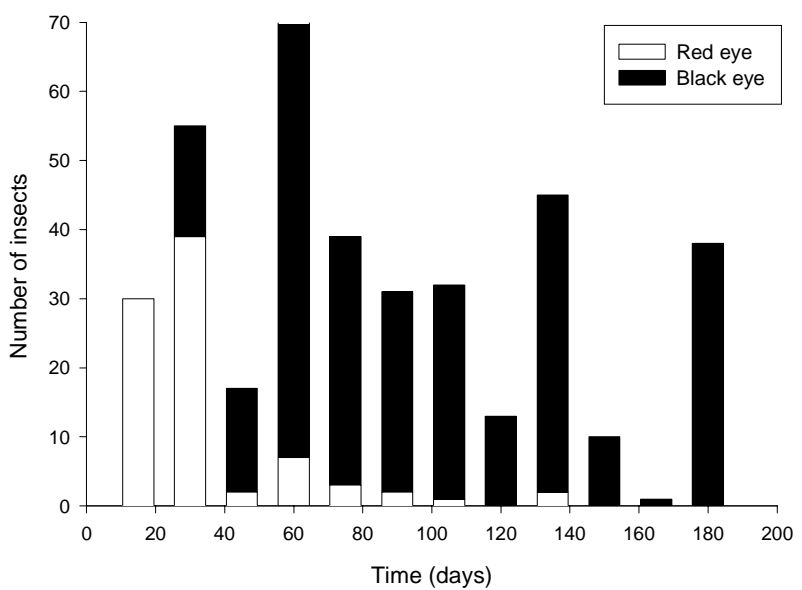

Fig. 3: eye colour phenotype of Triatoma infestans descendants from recessive females (red-eye) and recessive males. After the first oviposition, the males were substituted for the dominants (black-eye) (Group 1). 


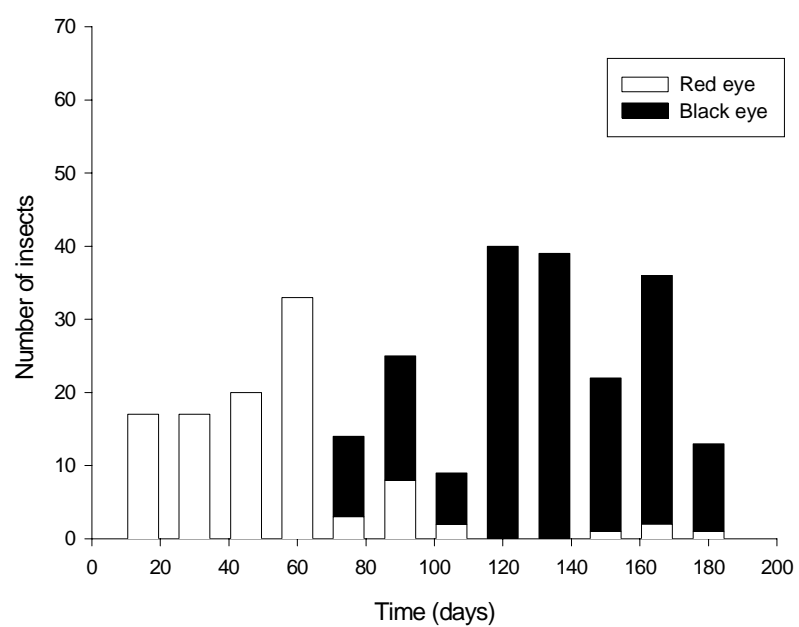

Fig. 4: eye colour phenotype of Triatoma infestans descendants from recessive females (red-eye) and recessive males. Two months after the beginning of the oviposition, the males were substituted for dominant males (black-eye) (Group 2).

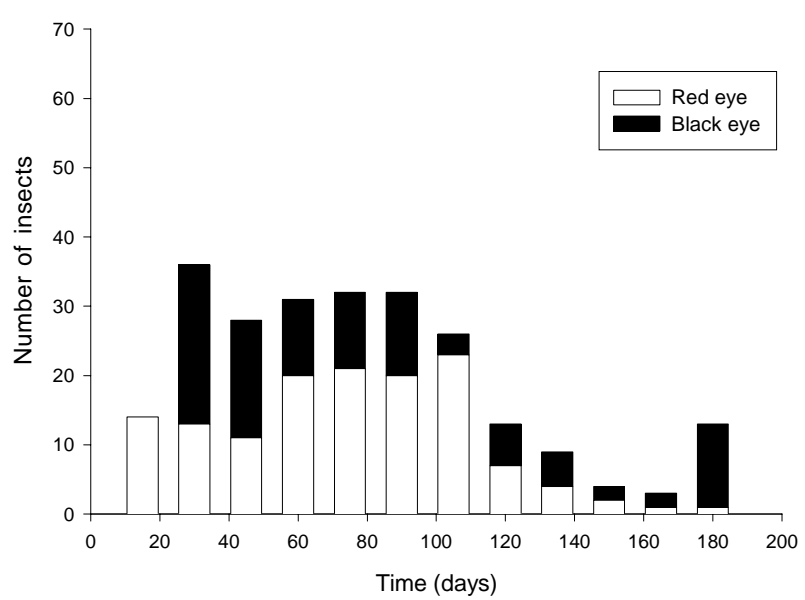

Fig. 5: eye colour phenotype of Triatoma infestans descendants from recessive females (red-eye) assembled with recessive males for 15 days and then with dominant males (black-eye) for a further 15 days (Group 6).

was no significant difference in oviposition rate or egg hatch rate when the female remained with the male or if the male was removed as oviposition began. In groups 6 and 7 , where the females were firstly kept with red-eye or homozygous black-eye males for 15 days and then with males of the other phenotype for a further 15 days, the overall numbers of offspring with each phenotype were similar in both cases, with a significant predominance of black-eye phenotypes in both cases (Figs 6,7). No differences in oviposition rate or egg hatch rate were observed. The results from groups 1, 2 and 5 did not indicate mating preference or dominance of either phenotype. The results from groups 6 and 7 indicate that sperm from black-eye males may survive longer in the spermatheca than sperm from red-eye males.

\section{DISCUSSION}

Black-eye is the most frequent form observed in $T$. infestans, although red-eye forms have been encountered

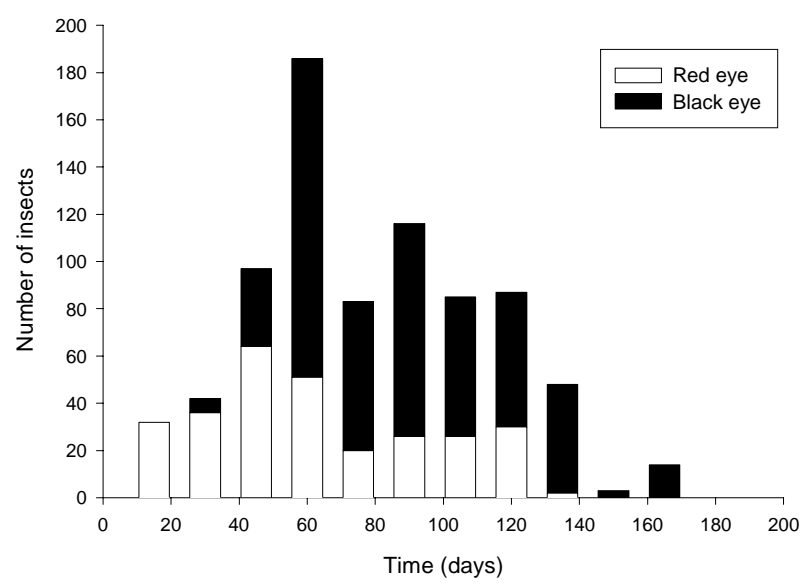

Fig. 6: eye colour phenotype of Triatoma infestans descendants from recessive females (red-eye) assembled with dominant males (black-eye) for 15 days and then with recessive males (red-eye) for a further 15 days (Group 7).

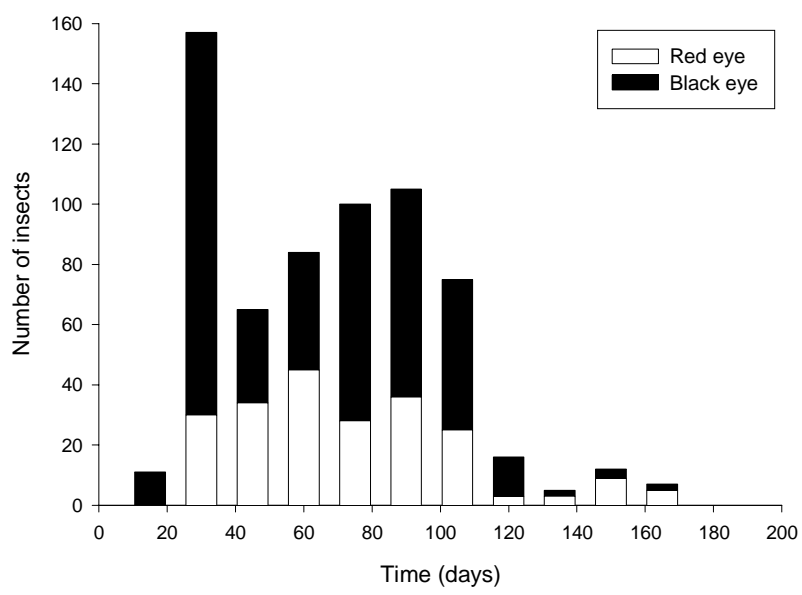

Fig. 7: eye colour phenotype of the Triatoma infestans descendants from recessive females (red-eye) assembled with recessive and dominant males (red and black-eye, respectively), simultaneously (Group $5)$.

in various natural populations. The first published report of the red-eye form was by Noé and Silva (1949) in Chile. These authors denoted the form as a new subspecies ( $T$. infestans erythrophthalmus, subsequently synonymized by Lent \& Wygodzinsky 1979) and attributed the red-eye colour to a recessive gene on the $\mathrm{X}$ chromosome. In fact, their published data would be consistent with an autosomal recessive, as verified by subsequent authors examining red-eye forms of $T$. infestans from Argentina (Wygodzinsky \& Briones 1954, 1955) and Bolivia (Dujardin \& Bermúdez 1986). Our studies in preparation for this paper also confirm that red-eye is associated with a single autosomal recessive following classical Mendelian inheritance. It would seem likely that red-eye might be associated with impaired vision, but our results suggest that even if this is so, there is no impairment of mating attractiveness, nor of mating success. All crosses reported here gave similar rates of oviposition and fertility, irrespective of parental phenotypes. 
Data of Barlow (1955) and Perlowagora-Szumlewicz (1968) demonstrated that oviposition of T. infestans generally begins 15 days after mating, probably coinciding with the sexual maturity of the insects and requiring a minimum volume of blood to initiate oogenesis. In the present work we found that only $13.6 \%$ of the insects began oviposition at 15 days after formation of the couples. We suspect that this may be due to immaturity of the females, which were introduced to the males almost immediately after emergence. According to Manrique and Lazzari (1994), T. infestans females tend to avoid males for up to 16 days after adult emergence, with female receptiveness then increasing with age. In experiments where the original red-eye males were replaced with black-eye males, manifestation of the new phenotype of the offspring began after 15 days, which would therefore seem to be the minimum period necessary for maturation and fertilization of the eggs.

In this study, we observed no significant differences in the total number of eggs laid, after eight months under observation, in relation to the mating scheme. This is consistent with various other studies indicating that, given at least one successful copulation, the number of eggs laid per female is conditioned primarily by blood intake (eg. Schofield 1982). We also observed no significant difference in the egg hatching rate in relation to the mating scheme, indicating that both types of spermatazoa - redeye or black-eye phenotypes - are equally fertile. In spite of this, it is clear that sperm from successive or multiple matings can be used for egg fertilization. Where females were maintained continuously with males of both phenotypes, the offspring reflected the parental phenotypes in similar proportions (group 5). Similarly, when females were kept first with red-eye males for 15 days, and then maintained with black-eye males, phenotypic substitution of the offspring was observed to give a final predominance of black-eyed offspring (group 6). Remarkably however, when females were first kept with black-eye males for 15 days, and then maintained with red-eye males, the phenotypic substitution of the offspring also led to a predominance of black-eye offspring (group 7). From this, we conclude that multiple matings clearly occurred in both cases, but sperm from black-eye males appears to have had some advantage over sperm from red-eye males. Since the results from other crossings showed no selective advantage for sperm of either phenotype when both types of male were present, we interpret these results to suggest that sperm from black-eye males may be able to survive longer in the spermatheca, offering a selective advantage when opportunities for successive mating become restricted. The spermatic competition has been suggested for other insects which show polyandry reproduction (Thornhill \& Alcock 1983).

Overall, our results support the idea of a polyandrous reproductive system in T. infestans, in the sense that multiple matings clearly can occur during the reproductive life of the female, leading to offspring from several males. However, our results also show that a single mating can be sufficient to maintain fertility throughout the reproductive life of the female. Further work will be required to ascertain the dynamics of sperm utilization from the stock held in the spermatheca, but the indication that sperm from red-eye males may be of shorter viability compared to sperm from black-eye males could help explain why red-eye mutants of $T$. infestans are uncommonly seen in natural populations, and fail to persist except under continuous laboratory selection.

\section{ACKNOWLEDGEMENTS}

To Dr João Carlos Pinto Dias for bringing the red-eyed insects to the Laboratório de Triatomíneos e Epidemiologia da Doença de Chagas and Dr Rodolfo Carcavallo for catching the insects in Cruz Del Eje, Argentina. This work benefitted from international collaboration through the ECLAT network.

\section{REFERENCES}

Barlow CA 1955. The fecundity of Aedes hexodontus Dejar (Culicidae) in the laboratory. Canad J Zood 33: 420-427.

Borba AM 1972. Biologia de Panstrongylus megistus (Burm, 1835) em Condições Artificiais. Aspectos Ecológicos e Epidemiológicos desta Espécie no Estado do Paraná (Hemiptera, Reduviidae, Triatomine), Thesis, Universidade Federal do Paraná, 100 pp.

Corrêa RR 1954. Estudos sobre a morfologia esterna do gênero Triatoma Laporte, 1833 (Hemiptera, Reduviidae). Folia Clin Biol 22: 23-50.

Dujardin JP, Bermúdez H 1986. Transmision hereditaria de fenotipo "Ojos Rojos" en Triatoma infestans (Hemiptera Reduviidae). Bol Cient CENETROP 12: 38-42.

Lent H, Wygodzinsky P 1979. Revision of the Triatominae (Hemiptera, Reduviidae, Triatominae) and their significance as vectors of Chagas' disease. Bull Am Mus Nat Hist NY 163: 123-520.

Lima MM, Jurberg P, Almeida JR 1987. Behavior of triatomines (Hemiptera: Reduviidae) vectors of Chagas disease. IV Fecundity, fertility and longevity of Panstrongylus megistus (Burm, 1835) pairs and virgin starved under laboratory conditions. Mem Inst Oswaldo Cruz 82: 501-509.

Manrique G, Lazzari CR 1994. Sexual behaviour and stridulation during mating in Triatoma infestans (Hemiptera: Reduviidae). Mem Inst Oswaldo Cruz 89: 629-633.

Neiva A 1910. Informações sobre a biologia de Conorhinus megistus (Burm, 1835). Mem Inst Oswaldo Cruz 2: 206212.

Noé J, Silva R 1949. Una variedae de Triatoma infestans (Klug, 1834). Bol Inf Paras Chil 4: 4-5.

Perlowagora-Szumlewicz A 1968. Laboratory colonies of Triatominae, biology and population dinamics. Scent Publ PAHO 318: 63-82.

Pessoa SB, Martins AV 1982. Parasitologia Médica, 11 ed., Ed. Guanabara Koogan, Rio de Janeiro, 872 pp.

Schofield CJ 1982. The role of blood intake in density regulation of populations of Triatoma infestans (Klug) (Hemiptera, Reduviidae). Bull Ent Res 72: 617-629.

Schofield CJ 1994. Triatominae - Biologia y Control, Eurocommunica publications, West Sussex, UK, 78 pp.

Thornhill R, Alcock J 1983. The Evolution of Insect Mating Systems, Harvard University Press, Cambridge, USA, 547 pp.

Wygodzinsky P, Briones S 1954. Nota sobre mutaciones del color del ojo en Triatoma (Klug). Anal Inst Med Reg De la Unv Nac de Tucumán 4: 115-118.

Wygodzinsky P, Briones S 1955. Nota adicional sobre mutantes del color en Triatoma infestans (Klug). Anal Inst Med Reg de la Unv Nac de Tucumán 4: 241-243. 